\title{
THE LINK BETWEEN VARICELLA AND IMMUNE SYSTEM: WHICH CHILDREN WILL DEVELOP ACUTE CEREBELLITIS?
}

Bozzola Elena ${ }^{1}$, Carsetti Rita ${ }^{2}$, Piano Mortari Eva ${ }^{2}$, Marco Masci ${ }^{1}$, Di Franco Silvia ${ }^{1}$, Scanni Gianluca $^{1}$, Villani Alberto ${ }^{1}$.

${ }^{1}$ University/hospital Department of Pediatrics, Pediatric and Infectious Diseases Unit, Bambino Gesù Children's Hospital, IRCCS, Rome, Italy

${ }^{2} \mathrm{~B}$ cell Physiopathology Unit, Immunology Research Area, Bambino Gesù Children Hospital,

Rome, Italy.

Methods. We included in the study patients admitted at Bambino Gesù Children Hospital, Roma, Italy for cerebellitis in varicella. Inclusion criteria was age between 3 and 18 years. Laboratory tests included: antibodies titles against vaccine antigens (tetanus, Haemophilus influenzae B, Streptococcus pneumoniae, Bordetella pertussis and Hepatitis B), serum immunoglobulin concentration, evaluation of lymphocyte subpopulations ( CD3, CD4, CD8, CD19, CD16/56, central memory and effector memory T cells, B cell memory), in vitro antibody production. Results. Twenty-five patients were included in the study. At the outpatient control, all patients were in good clinical conditions, without either fever or infectious disease. The medical history was collected for each patient and was negative for recurrent or severe infection, except for varicella cerebellitis. Certificates of vaccination were regular, according to chronological age. Nevertheless, immunological laboratory exams were altered in most of the patients. Figure 1 summarizes the results.

Group 1: 13 follow-up at least 1 year after the diagnosis

\begin{tabular}{|c|c|c|}
\hline & $\begin{array}{l}3 \text { with a reduced or absent in } \\
\text { vitro antibody production }\end{array}$ & \multirow{3}{*}{$\begin{array}{c}5 \text { had } \\
\text { multiple } \\
\text { defects }\end{array}$} \\
\hline $\begin{array}{l}11 \text { with an immunological } \\
\text { impairment }\end{array}$ & $\begin{array}{l}2 \text { had a decreased number of } \\
\text { switched memory B cells }\end{array}$ & \\
\hline & $\begin{array}{l}10 \text { had insufficient response to } \\
\text { vaccination }\end{array}$ & \\
\hline
\end{tabular}

2 without immunological impairment

\begin{tabular}{|l|l|} 
& $\begin{array}{l}\text { 9 with an immunological } \\
\text { impairment }\end{array}$ \\
& \\
\hline $\begin{array}{l}\text { Group 2: 12 follow-up } \\
\text { in the first year after } \\
\text { the diagnosis }\end{array}$ & \\
\hline & $\begin{array}{l}\text { 3 without immunological } \\
\text { impairment }\end{array}$ \\
\hline
\end{tabular}

\begin{tabular}{|l|c|}
$\begin{array}{l}4 \text { with a reduced or absent in } \\
\text { vitro antibody production }\end{array}$ & \\
\cline { 1 - 1 } $\begin{array}{l}3 \text { had a decreased number of } \\
\text { switched memory B cells }\end{array}$ & $\begin{array}{c}5 \text { had } \\
\text { multiple } \\
\text { defects }\end{array}$ \\
\cline { 1 - 2 } $\begin{array}{l}8 \text { had insufficient response to } \\
\text { vaccination }\end{array}$ & \\
\hline
\end{tabular}

